\title{
Discretionary provisioning practices among Western European banks
}

Article in Journal of Financial Economic Policy · February 2017

DOI: 10.1108/JFEP-07-2016-0049

CITATIONS

0

1 author:

\section{Peterson K Ozili}

University of Essex

14 PUBLICATIONS 19 CITATIONS

SEE PROFILE
READS

19

Some of the authors of this publication are also working on these related projects: 
Discretionary Provisioning Practices among Western European Banks

Peterson K Ozili

University of Essex

United Kingdom 


\title{
Discretionary Provisioning Practices among Western European Banks
}

\begin{abstract}
The purpose of this study is to investigate whether discretionary provisioning by Western European banks is driven by income smoothing or credit risk considerations. We find evidence that discretionary provisioning by Western European banks is driven by income smoothing incentives in the post-financial crisis period, particularly, among listed banks. Also, we observe that discretionary provisioning is significantly influenced by credit risk factors, mainly, non-performing loans and loan growth. Also, we find that discretionary provisioning by Western European banks is procyclical with fluctuations in the economic cycle. Overall, the implication of the findings is that discretionary provisioning among Western European banks is driven by both income smoothing and credit risk considerations.
\end{abstract}

Keywords: Managerial Discretion, Income smoothing, Bank regulation, Loan loss provisions, Western Europe, Procyclicality.

JEL Code: C21, C23, G21, M41

Published Version: http://www.emeraldinsight.com/doi/abs/10.1108/JFEP-07-2016-0049

To cite: Ozili, P. K. (2017). Discretionary provisioning practices among Western European banks. Journal of Financial Economic Policy, Vol. 9 No. 1. 


\section{Introduction}

In this paper, we investigate whether discretionary provisioning among Western European banks is driven by credit risk or income smoothing considerations. Bank loan loss provisions play an important role in micro-prudential regulation of banks. Under Basel II, bank capital should be sufficient to cover unexpected losses while loan loss provisions (and loan loss reserves) should cover expected losses on bank loan portfolio (BCBS, 2004). Accordingly, European banks are required to set aside 'specific provisions' to cover probable impaired loans and make 'general provisions' to cover loan losses arising from fluctuations in the business cycle (FSF, 2009). After the 2007 to 2009 financial crisis, bank regulators in Europe introduced strict rules on bank provisioning and risk-taking behaviour, and such rules were intended to ensure that the provisioning of Western European banks is driven by credit risk considerations. In this paper, we argue that discretionary provisioning will be driven by credit risk considerations if bank managers are more concerned about the credit quality of their loan portfolio in the post-financial crisis period, or discretionary provisioning will be driven by income smoothing incentives if bank managers are more concerned about earnings stability (or opportunistic earnings management) in the post-financial crisis period. To date, it is not clear whether the provisioning behaviour of Western European banks is driven by credit risk or income smoothing considerations particularly after the 2007 to 2009 financial crisis.

Moreover, prior European studies examine bank provisioning practices in the pre-crisis period [e.g. Leventis et al, 2011 (examine 1999 to 2008); Curcio and Hasan, 2015 (examine 1996 to 2006); Skala, 2015 (examine Central European banks from 2004 to 2012)]. In contrast to Skala (2015), the present study examine the case of Western European banks to investigate whether loan loss provisioning of Western European banks is driven by credit risk or income smoothing considerations before and after the financial crisis.

The study employs bank data from Bankscope from 16 Western European countries and finds that discretionary provisioning by Western European banks is driven by both income smoothing and credit risk considerations. This study contributes to the literature that investigate the determinants of loan loss provisions. We add to this strand of literature by providing evidence that managerial provisioning decisions in Western Europe is driven by both income smoothing and credit risk considerations. Also, by focusing on the context of Western European banks, we contribute to the income smoothing literature by providing another evidence for income smoothing in Europe.

The remainder of the paper is organised as follows. Section 2 presents the literature review and develops the hypotheses. Section 3 presents the data and methodology. Section 4 presents the findings and Section 5 concludes.

\section{Literature Review}

Kleimeier (2002) and Evans et al (2008) demonstrate that banking in Western Europe has become more competitive, more concentrated and more integrated in the last decade just before the 2008 financial crisis. It was during this period (characterized by increased bank competition, concentration, and market integration) that Leventis et al (2011) examine income smoothing practices among 91 listed European banks during 1999 to 2008 period. They investigate the impact of accounting disclosure (IFRS) on banks' incentive to use loan loss provisions to smooth income and to manage regulatory capital. They find evidence for income smoothing via provisions. However, they observe that bank income smoothing behaviour is reduced after IFRS adoption in Europe. Bonin and Kosak (2013) investigate the provisioning practices of banks in emerging European countries during the 
1997 to 2010 period. They find evidence for income smoothing, capital management and macroeconomic procyclicality. Also, Curcio and Hasan (2015) investigate the provisioning and income smoothing practices of Euro-Area and non-Euro Area credit institutions using pre-crisis bank data, during 1996 to 2006 period. They find that non-Euro Area banks use provisions to smooth income. However, they observe that Euro-Area banks did not smooth income possibly because they were concerned about the credit quality of bank loan portfolio. Jointly, Bonin and Kosak (2013) and Curcio and Hasan (2015)'s findings show that discretionary provisioning in the pre-crisis period was driven by income smoothing and capital management considerations than by credit risk considerations. Other non-EU studies find similar evidence for income smoothing in the pre-crisis period (e.g. Bhat, 1996; Lobo and Yang, 2001; Kanagaretnam et al, 2004; El Sood, 2012; Balboa et al, 2013; Ozili, 2016, etc.).

In contrast to the pre-crisis banking environment, the post-crisis banking environment in Western Europe has become more regulated after the 2008 crisis (Temming, 2014), and only few studies use post-crisis EU bank data to investigate the impact of the regulatory environment on loan loss provisioning practices of EU banks. For example, Olszak et al (2016) investigate the determinants of bank loan loss provisions and procyclicality. They find that loan loss provisions of large and listed commercial banks is procyclical with business cycle fluctuations. Also, they observe that better investor protection and bank capital regulation reduce the procyclicality of loan loss provisions. Skala (2015) investigates the case of Central European banks during the 2004 to 2012 period and find that banks in the region use loan loss provisions to smooth income, and that provisions is procyclical with fluctuations in the economic cycle. Overall, there are few studies on bank loan loss provisioning practices in the post-financial crisis period.

To develop the hypothesis, we predict a strong positive association between loan loss provisions and bank earnings if Western European banks increase (decrease) provisions to lower (increase) high (low) earnings in order to report stable earnings over time. This is consistent with the argument of the income smoothing hypothesis (Ahmed et al, 1999; Fonseca and Gonzalez, 2008; Leventis et al, 2011).

Hypothesis: Western European banks use loan loss provisions to smooth bank earnings.

On the other hand, we predict a negative association between loan loss provisions and bank earnings if bank provisions is driven by credit risk considerations rather than by income smoothing consideration. To date, conclusions to support the income smoothing hypothesis are mixed in the income smoothing literature (e.g. Ahmed et al, 1999; Lobo and Yang, 2001; Kanagaretnam et al, 2004).

\section{Data and Methodology}

\subsection{Data}

The bank sample consists of selected Western European banking institutions in the Bankscope database. The countries include: United Kingdom, Denmark, Finland, Ireland, Greece, Portugal, Belgium, Austria, Italy, France, Luxemburg, Spain, Netherland, Germany, Sweden, and Norway. The sample period cover the 2004 to 2013 period. All sample banks have December 31 fiscal year ends. The sample includes banks with required data for our tests from 2004 to 2013. Banks that have loan loss provisions data in Bankscope database for at least two consecutive years were included in the sample in order to control for quality of bank financial reporting. Year-2008 bank-year observations were excluded from the analysis to control for the adverse effect of the financial crisis from affecting our inference. The resulting final sample yields 114 banks consisting of 22 listed banks and 92 nonlisted banks. 


\subsection{Methodology}

The baseline model specification adopted in this study follows the existing literature.

$$
\begin{gathered}
\text { LLP it }=\alpha 0+\alpha 1 N P L i t+\alpha 2 \text { LOAN it }+\alpha 3 \text { EBTP it }+\alpha 4 \text { CAR it }+\alpha 5 \Delta \text { GDPjt } \\
+\alpha 6 S I Z E i t+\varepsilon i t \quad \ldots \ldots \ldots(1)
\end{gathered}
$$

Where,

LLP = Ratio of loan loss provisions to total assets for bank $\mathrm{i}$ at time $\mathrm{t}$.

$\mathrm{NPL}=$ Ratio of impaired loans to gross loans for bank i at time $\mathrm{t}$

LOAN $=$ Change in gross loan outstanding for bank $\mathrm{i}$ at time $\mathrm{t}$.

$\mathrm{CAR}=$ Ratio of actual tier 1 regulatory capital to risk-weighted assets for bank $\mathrm{i}$ at time $\mathrm{t}$.

$\mathrm{EBTP}=$ Ratio of earnings before taxes and loan loss provisions to total assets for bank $\mathrm{i}$ at time $\mathrm{t}$.

SIZE $=$ Natural logarithm of total assets for bank $\mathrm{i}$ at time $\mathrm{t}$.

$\Delta \mathrm{GDP}=$ Change in gross domestic product for country $\mathrm{j}$ at period $\mathrm{t}$.

$\varepsilon=$ Error term.

Consistent with prior studies, the explanatory variables include non-performing loan (NPL), loan growth (LOAN), tier 1 capital (CAR), bank size (SIZE) and gross domestic product growth rate $(\triangle \mathrm{GDP})$. NPL reflects the credit quality of banks (Beaver and Engel, 1996; Ahmed et al, 1999). NPL, an ex-post measure of the quality of bank loan portfolio, is considered to contain information on bank risk that is not captured by traditional measures of credit risk (Ahmed et al, 1999). We predict a positive sign for NPL coefficient because banks will increase provisions when they expect higher loan defaults. We use loan growth (LOAN) as a proxy for contemporaneous credit risk (Lobo and Yang, 2001; Laeven and Majnoni, 2003; Kanagaretnam et al, 2003; Bushman and Williams, 2012). A positive sign for LOAN variable indicates that banks would increase provisions when loan supply increases to compensate for contemporaneous credit risk concerns. However, Lobo and Yang (2001) point out that a negative sign on the LOAN variable may be expected if there is improved quality of incremental loans which in turn would require fewer provisioning. Following the argument of Laeven and Majnoni (2003), we predict a positive sign for LOAN coefficient. CAR variable reflects banks' use of provisions to manage regulatory capital (Ahmed et al, 1999; Anandarajan et al, 2007; Kilic et al, 2012; Bonin and Kosak, 2013). We expect a negative sign for CAR coefficient if banks increase provisions when they have low Tier 1 capital ratio. Also, we use the natural logarithm of total assets (SIZE) as a proxy for bank size. Kilic et al (2012), Ozili (2015) and Curcio and Hasan (2015) also use the SIZE variable. Large banks are considered to have higher levels of business activities and tend to keep more provisions to compensate for their high level of business activities compared to smaller banks (Anandarajan et al, 2003). Accordingly, we expect a positive relationship between SIZE and LLP. At country level, $\Delta$ GDP controls for economic fluctuations for each country. The use of $\Delta$ GDP to capture changes in economic activity for each country is common across the literature (e.g. Bikker and Metzemakers, 2005; Floro, 2010, etc.). Consistent with prior studies, we expect a negative relationship between LLP and $\triangle \mathrm{GDP}$ because banks will increase provisions during bad economic periods (recessionary periods), and keep fewer provisions during good economic periods (Laeven and Majnoni, 2003; Bikker and Metzemakers, 2005; Floro, 2010, etc.).

The coefficients of interest in the analysis are NPL, LOAN, EBTP and POST*EBTP coefficients. The income smoothing variable (EBTP) is included to test whether Western European banks use loan loss 
provisions to smooth income. We introduce POST dummy variable that take the value ' 1 ' for the post-financial crisis period (2009-2013) and ' 0 ' for the pre-crisis period (2004-2007). We interact POST with EBTP to detect whether income smoothing via provisions is pronounced in the postfinancial crisis period compared to the pre-financial crisis period. The use of POST*EBTP interaction term is consistent with Anandarajan et al (2007) who examine the case of Australian banks. We interpret a significant and positive sign for EBTP and POST*EBTP coefficients as evidence for the use of provisions to smooth income. We also interpret a significant and positive sign for NPL and LOAN coefficients as evidence for the use of provisions for credit risk purposes because banks will keep more provisions when they expect higher NPL and LOAN.

\section{Empirical Result}

\subsection{Descriptive Statistics and Correlation}

Descriptive statistics for the full sample from 2004 to 2013 is presented in Table 1. Loan loss provisions (LLPs), on average, is $0.37 \%$ while pre-provisions and pre-tax earnings (EBTP) is $0.74 \%$. Capital management variable (CAR), on average, is $11.34 \%$ while bank size (SIZE) is 18.59. Change in gross loan (LOAN) is $4.53 \%$ while non-performing loan (NPL), on average, is $4.32 \%$.

\section{[Insert Table 1]}

Table 2 reports the correlation coefficients and the associated p-values for each variable. LLP is positively correlated with EBTP (0.085), and suggests that an increase in earnings (EBTP) is followed by increase in loan loss provisions (LLP). LLP is negatively correlated with SIZE (-0.058). On the other hand, LLP is negatively correlated with CAR (-0.037), and supports the capital management hypothesis that propose a negative relationship between CAR and LLP. LLP coefficient is negatively correlated with $\triangle \mathrm{GDP}(-0.159)$, and indicates that provisioning by Western European banks is procyclical with fluctuations in the economic cycle. LLP is negative and significantly correlated with LOAN (-0.151), and indicates that higher bank lending is followed by fewer provisions. LLP is positively correlated with NPL (0.768), and indicates that banks increase provisions when they expect higher loan losses. Finally, the correlation between the independent variables are not too high, hence, multicollinearity is not an issue in the analysis.

[Insert Table 2]

\subsection{Estimation Results}

The result is reported in Table 3. Column 1 reports the pooled regression results for the full bank sample. EBTP coefficient $(\mathrm{t}=2.16)$ is positive and significant at $5 \%$ level, and provide support for the income smoothing hypothesis. Leventis et al (2011) find similar evidence. POST*EBTP coefficient is negative and insignificant in Column 2, and indicates that the use of provisions to smooth earnings is not pronounced during the post-financial crisis period compared to the pre-financial crisis period.

With respect to the control variables in Column 1, NPL coefficient $(t=8.28)$ is positive and significant at $1 \%$ level, and indicates that Western European banks increase provisions when they expect higher non-performing loans. LOAN coefficient $(t=3.57)$ is positive and significant, and implies that Western European banks keep more provisions when they increase bank lending. CAR coefficient $(\mathrm{t}=-0.11)$ is negative and insignificant. SIZE coefficient $(\mathrm{t}=-0.49)$ is insignificant. $\Delta$ GDP coefficient $(\mathrm{t}=-3.37)$ is negative and significant at $1 \%$ level, and indicates that provisioning by Western European banks is procyclical with fluctuations in the economic cycle. Interestingly, $\Delta$ GDP coefficient is significant in all estimation in Table 3. 
[Insert Table 3]

\subsection{Sensitivity Analysis}

First, we test whether listed ${ }^{1}$ banks use provisions to smooth income. The result is reported in Column 3 of Table 3. LISTED*EBTP coefficient is insignificant. Secondly, we use the interaction term LISTED*POST*EBTP to test whether income smoothing is pronounced among listed banks in the post-crisis period compared to non-listed banks in the pre-crisis period. LISTED*POST*EBTP coefficient is insignificant in Column 4 while the coefficient of the credit risk variables (NPL and LOAN) remain significant. Further, we divide the full sample into two sub-samples: listed banks and non-listed banks to test whether listed and non-listed banks use provisions to smooth reported earnings during the post-crisis period relative to the pre-crisis period. For the listed banks sub-sample (Column 6), POST*EBTP coefficient is positive and significant, and implies that listed banks use provisions to smooth income to a greater extent during the post-financial crisis period compared to the pre-financial crisis period. For the non-listed banks sub-sample (Column 8), POST*EBTP coefficient is insignificant, and implies that non-listed banks do not use provisions to smooth income to a greater extent in the post-financial crisis period compared to the pre-financial crisis period.

\section{[Insert Table 3]}

Furthermore, in Table 4 we perform additional tests with respect to the sample period. We divide the full sample into two sub-samples: pre-financial crisis period (2004-2007) and the post-financial crisis period (2009-2013). EBTP coefficient is positive and significant in Column 1 and 3, and indicates that banks use provisions to smooth income in the pre-and post-crisis period while the coefficient of the credit risk variables (NPL and LOAN) also remain significant. However, EBTP coefficient is more significant in the post-crisis period. This suggests that provisioning by Western European banks during the post-crisis period is driven by income smoothing and credit risk considerations. Finally, we use the pre- and post-crisis subsample category to test again whether listed banks use provisions to smooth income to a greater extent compared to non-listed banks. LISTED*EBTP coefficient is insignificant in Column 2 and 4 while the coefficient of the credit risk variables (NPL and LOAN) remain significant.

[Insert Table 4]

\section{Conclusion}

In this study, we investigate whether discretionary provisioning by Western European banks is driven by income smoothing or credit risk considerations. We find evidence that discretionary provisioning by Western European banks is driven by income smoothing incentives in the post-financial crisis period, particularly, among listed banks. We also find that bank provisioning is procyclical with fluctuations in the economic cycle. Also, we observe that credit risk factors (NPLs and LOANs) significantly influence the level of bank provisions throughout the analysis. Hence, we conclude that

\footnotetext{
${ }^{1}$ We distinguish between listed and non-listed banks based on the list of companies provided available at the London Stock Exchange (LSE) updated as at 30th April, 2015. We use the London Stock Exchange as a proxy for the capital market because it is considered to be the most diverse capital market in Europe with regional company listing in Europe. The classification yields 22 listed banks and 92 non-listed banks. We note that the small number of listed bank may affect our inference.
} 
discretionary provisioning among Western European banks is driven by both income smoothing and credit risk considerations.

Assuming one goal of bank supervisors is to ensure that discretionary provisions is driven solely by credit risk considerations, our empirical results confirm that discretionary provisioning by Western European banks reflects credit risk considerations. However, for the purpose of policy making, bank supervisors in Western Europe should find ways to ensure that discretionary provisioning is driven solely by credit risk considerations while discouraging the use of provisions to smooth income. Future research could investigate other credit risk factors that influence the level of discretionary provisions among Western European banks. Also, future research could investigate whether discretionary provisions is influenced by the risk culture of banks in Western Europe, Central Europe and Emerging Europe.

\section{References}

Ahmed, A.S., Takeda, C. and Thomas, S. (1999), "Bank Loan Loss Provisions: A Re-examination of Capital Management, Earnings Management and Signaling Effects", Journal of Accounting and Economics, Vol. 28, pp. 1-25.

Anandarajan, A., Hasan, I., and Lozano-Vivas, A. (2003), "The Role of Loan Loss Provisions in Earnings Management, Capital Management, and Signaling: The Spanish Experience”, Advances in International Accounting, Vol. 16, pp. 45-65.

Anandarajan, A, Hasan, I., and McCarthy, C. (2007), "Use of Loan Loss Provisions for Capital, Earnings Management and Signaling by Australian banks", Accounting and Finance, Vol 47, pp. 357379 .

Balboa, M., López-Espinosa, G., and Rubia, A. (2013), "Nonlinear Dynamics in Discretionary Accruals: An Analysis of Bank Loan Loss Provisions", Journal of Banking and Finance, Vol. 37, No. 12, pp. 5186-5207.

Beaver, W and Engel, E. (1996), "Discretionary Behavior with Respect to Allowance for Loan Losses and the Behavior of Security Prices", Journal of Accounting and Economics, Vol. 22, pp. 177-206.

BCBS (2004), "International Convergence of Capital Measurement and Capital Standards: a Revised Framework", Basel Committee on Banking Supervision, June (www.bis.org).

Bhat, V. N. (1996), "Banks and Income Smoothing: An Empirical Analysis", Applied Financial Economics, Vol. 6 No. 6, pp. 505-510.

Bikker, J. A., and Metzemakers, P. A. (2005), "Bank Provisioning Behaviour and Procyclicality”. Journal of International Financial Markets, Institutions and Money, Vol. 15, No. 2, pp. 141-157.

Bonin, J., and Kosak, M. (2013), "Loan Loss Provisioning in Emerging Europe: Precautionary or ProCyclical?" Wesleyan University, Department of Economics.

Bushman, R. M., and Williams, C. D. (2012), "Accounting Discretion, Loan Loss Provisioning, and Discipline of Banks' Risk-taking”, Journal of Accounting and Economics, Vol. 54 No. 1, pp. 1-18.

Curcio, D., and Hasan, I. (2015), "Earnings and Capital Management and Signalling: the Use of Loan Loss Provisions by European Banks", The European Journal of Finance, Vol. 21 No. 1, pp. 26-50.

El Sood, H., A. (2012), "Loan Loss Provisions and Income Smoothing in US Banks Pre and Post Financial Crisis”, International Review of Financial Analysis, Vol. 25, pp. 64-72. 
Evans, P., Hasan, I., and Lozano-Vivas, A. (2008), "Deregulation and Convergence of Banking: The EU experience", Finnish Economic Papers, Vol. 21, No. 2, pp. 104-117.

Financial Stability Forum. (2009), "Report of the Financial Stability Forum on Addressing Procyclicality in the Financial System", April 2, Available at:

(http:/www.financialstabilityboard.org/publications/r_0904a.pdf). Accessed 7th August, 2015.

Floro, D. (2010), "Loan Loss Provisioning and the Business Cycle: Does Capital Matter? Evidence from Philippine Banks”, Bank for International Settlements Research Paper.

Fonseca, A.R, and Gonzalez, F (2008), "Cross-country Determinants of Bank Income Smoothing by Managing Loan Loss Provisions." Journal of Banking and Finance Vol. 32 No. 2, pp. 217-228.

Kilic, E., Lobo, G. J., Ranasinghe, T., and Sivaramakrishnan, K. (2012), "The Impact of SFAS 133 on Income Smoothing by Banks through Loan Loss Provisions”, The Accounting Review, Vol. 88 No. 1, pp. 233-260.

Kanagaretnam, K., Lobo, G.J and Mathieu, R. (2003), "Managerial Incentives for Income Smoothing through Bank Loan Loss Provisions", Review of Quantitative Finance and Accounting, Vol. 20, pp. 63-80.

Kanagaretnam, K, Lobo, G. J., and Yang, D. (2004), "Joint Tests of Signaling and Income Smoothing through Bank Loan Loss Provisions", Contemporary Accounting Research, Vol. 21 No. 4, pp. 843884.

Kleimeier (2002), "Banking in Western Europe", The International Encyclopedia of Business and Management Thomson Learning. Available at: http://pub.maastrichtuniversity.nl/f14f1705-ae834958-b739-9350f40c6252. Accessed: 7th August, 2015.

Leventis, S., Dimitropoulos, P. E., and Anandarajan, A. (2011), "Loan Loss Provisions, Earnings Management and Capital Management under IFRS: The Case of EU Commercial Banks", Journal of Financial Services Research, Vol. 40 No. 1-2, pp. 103-122.

Lobo, G.J. and Yang, D.H. (2001), "Bank Managers' Heterogeneous Decisions on Discretionary Loan loss provisions", Review of Quantitative Finance and Accounting, Vol. 16 No. 3, pp. 223-250.

Olszak, M., Pipień, M., Kowalska, I., and Roszkowska, S. (2016), "What Drives Heterogeneity of Cyclicality of Loan Loss Provisions in the EU?", Journal of Financial Services Research, 1-42.

Ozili, P.K. (2015), "Loan Loss Provisioning, Income Smoothing, Signaling, Capital Management and Procyclicality: Does IFRS Matter? Empirical Evidence from Nigeria", Mediterranean Journal of Social Sciences, Vol 6 No.2, pp. 224-232.

Ozili, P.K. (2017), "Bank Earnings Smoothing, Audit Quality and Procyclicality in Africa. The Case of Loan Loss Provisions", Review of Accounting and Finance, Vol. 16, No. 2 Forthcoming.

Skała, D. (2015), "Saving on a Rainy Day? Income Smoothing and Procyclicality of Loan Loss Provisions in Central European Banks", International Finance, Vol. 18 No. 1, pp. 25-46.

Temming, M. (2014), "Effect of Pre-Crisis Capital on Stock Abnormal Return at Acquisition Announcements. The Case of the Western European Banking Sector during the 2008 Crisis". Available at: http://essay.utwente.nl/64742/1/Temming_MA_MB.pdf 


\section{List of Tables}

\begin{tabular}{|c|c|c|c|c|}
\hline \multicolumn{5}{|c|}{ Table 1: Summary of Descriptive Statistics } \\
\hline \multicolumn{5}{|c|}{ Full Sample (2004-2013) } \\
\hline Variable & Mean & Median & S.D & Observations \\
\hline LLP & 0.004 & 0.001 & 0.009 & 923 \\
\hline EBTP & 0.007 & 0.006 & 0.007 & 923 \\
\hline LOAN & 0.045 & 0.037 & 18.61 & 842 \\
\hline NPL & 0.043 & 0.024 & 5.95 & $6 / 1$ \\
\hline CAR $(\%)$ & 11.3 & 10.00 & 5.44 & 707 \\
\hline SIZE & 18.59 & 18.39 & 1.41 & 925 \\
\hline$\Delta \mathrm{GDP}$ & 1.59 & 2.14 & 2.67 & 1026 \\
\hline \multicolumn{5}{|c|}{$\begin{array}{l}\text { SIZE is the natural logarithm of total assets. LOAN is the loan growth rate or } \\
\text { change in gross loan outstanding. LLP is the ratio of loan loss provisions to } \\
\text { total assets. NPL is the ratio of impaired loans to gross loans. } \triangle \text { GDP is change } \\
\text { in gross domestic product. CAR is tier } 1 \text { regulatory capital to risk-weighted } \\
\text { asset ratio expressed in percentage. EBTP is the ratio of pre-provisions and pre- } \\
\text { tax earnings to total asset. }\end{array}$} \\
\hline
\end{tabular}

Table 2: Pearson Correlation Coefficients of Key Variables

\begin{tabular}{|c|c|c|c|c|c|c|c|}
\hline Correlation & LLP & NPL & LOAN & EBTP & CAR & $\Delta \mathrm{GDP}$ & SIZE \\
\hline LLP & 1.000 & & & & & & \\
\hline NPL & $\begin{array}{r}0.768 * * * \\
0.000\end{array}$ & 1.000 & & & & & \\
\hline LOAN & $\begin{array}{r}-0.151 * * * \\
0.000\end{array}$ & $\begin{array}{r}-0.321 * * * \\
0.000\end{array}$ & 1.000 & & & & \\
\hline EBTP & $\begin{array}{r}0.085 * * \\
0.048\end{array}$ & $\begin{array}{r}-0.005 \\
0.911\end{array}$ & $\begin{array}{r}0.268^{* * *} \\
0.000\end{array}$ & 1.000 & & & \\
\hline CAR & $\begin{array}{r}-0.037 \\
0.384\end{array}$ & $\begin{array}{r}-0.001 \\
0.975\end{array}$ & $\begin{array}{r}-0.271^{* * * *} \\
0.000\end{array}$ & $\begin{array}{r}-0.162 * * * \\
0.000\end{array}$ & 1.000 & & \\
\hline$\Delta \mathrm{GDP}$ & $\begin{array}{r}-0.159 * * * \\
0.000\end{array}$ & $\begin{array}{r}-0.126^{* * * *} \\
0.003\end{array}$ & $\begin{array}{r}0.289 * * * \\
0.000\end{array}$ & $\begin{array}{l}0.044 \\
0.303\end{array}$ & $\begin{array}{r}-0.077 * \\
0.075\end{array}$ & 1.000 & \\
\hline SIZE & $\begin{array}{r}-0.058 \\
0.175\end{array}$ & $\begin{array}{r}-0.050 \\
0.242\end{array}$ & $\begin{array}{r}-0.024 \\
0.576\end{array}$ & $\begin{array}{r}-0.098 * * \\
0.023\end{array}$ & $\begin{array}{r}-0.008 \\
0.850\end{array}$ & $\begin{array}{r}-0.036 \\
0.401\end{array}$ & 1.000 \\
\hline
\end{tabular}

$* * *, * *$ and $*$ denote significant difference at $0.01,0.05$ and 0.10 levels, respectively. EBTP is the ratio of pretax and pre-provisions earnings to total assets. SIZE is the natural logarithm of total assets. LOAN is the change in outstanding loans. LLP is the ratio of loan loss provisions to total assets. NPL is the ratio of impaired loans to gross loans. $\triangle \mathrm{GDP}$ is change in gross domestic product. CAR is tier 1 regulatory capital. 


\begin{tabular}{|c|c|c|c|c|c|c|c|c|c|}
\hline \multicolumn{10}{|c|}{ Table 3: Main Regression Result (OLS results) } \\
\hline & & \multicolumn{4}{|c|}{ Full Sample } & \multicolumn{2}{|c|}{ Listed Banks } & \multicolumn{2}{|c|}{ Non-Listed Banks } \\
\hline & & (1) & (2) & (3) & (4) & (5) & (6) & (7) & (8) \\
\hline Variable & $\begin{array}{l}\text { Exp } \\
\text { Sign } \\
\end{array}$ & $\begin{array}{c}\text { coefficient } \\
\text { t-statistic }\end{array}$ & $\begin{array}{c}\text { coefficient } \\
\text { t-statistic }\end{array}$ & $\begin{array}{l}\text { coefficient } \\
\text { t-statistic }\end{array}$ & $\begin{array}{l}\text { coefficient } \\
\text { t-statistic }\end{array}$ & $\begin{array}{l}\text { coefficient } \\
\text { t-statistic }\end{array}$ & $\begin{array}{c}\text { coefficient } \\
\text { t-statistic }\end{array}$ & $\begin{array}{c}\text { coefficient } \\
\text { t-statistic }\end{array}$ & $\begin{array}{c}\text { coefficient } \\
\text { t-statistic }\end{array}$ \\
\hline $\mathrm{c}$ & $?$ & $\begin{array}{l}-0.001 \\
(-0.15) \\
\end{array}$ & $\begin{array}{c}-0.0003 \\
(-0.07) \\
\end{array}$ & $\begin{array}{l}-0.001 \\
(-0.26) \\
\end{array}$ & $\begin{array}{l}-0.001 \\
(-0.12) \\
\end{array}$ & $\begin{array}{c}-0.007 * \\
(-1.71) \\
\end{array}$ & $\begin{array}{c}-0.009 * * \\
(-2.37) \\
\end{array}$ & $\begin{array}{l}-0.002 \\
(-0.36) \\
\end{array}$ & $\begin{array}{l}-0.003 \\
(-0.44) \\
\end{array}$ \\
\hline EBTP & + & $\begin{array}{c}0.104 * * \\
(2.16)\end{array}$ & $\begin{array}{l}0.121 \\
(1.15)\end{array}$ & $\begin{array}{l}0.084 \\
(1.57)\end{array}$ & $\begin{array}{l}0.086^{*} \\
(1.68)\end{array}$ & $\begin{array}{c}0.341 * * * \\
(7.17)\end{array}$ & $\begin{array}{c}0.174 * * \\
(2.38)\end{array}$ & $\begin{array}{l}0.077 \\
(1.30)\end{array}$ & $\begin{array}{l}0.164 \\
(1.22)\end{array}$ \\
\hline POST*EBTP & $+/-$ & & $\begin{array}{l}-0.024 \\
(-0.21)\end{array}$ & & & & $\begin{array}{c}0.277 * * * \\
(3.17)\end{array}$ & & $\begin{array}{l}-0.109 \\
(-0.74)\end{array}$ \\
\hline POST & $?$ & & $\begin{array}{l}-0.001 \\
(-0.77)\end{array}$ & & $\begin{array}{l}-0.002 \\
(-1.63) \\
\end{array}$ & & $\begin{array}{l}-0.002 \\
(-1.36)\end{array}$ & & $\begin{array}{c}-0.0003 \\
(-0.19)\end{array}$ \\
\hline NPL & + & $\begin{array}{c}0.001 * * * * \\
(8.28)\end{array}$ & $\begin{array}{c}0.001 * * * \\
(8.29)\end{array}$ & $\begin{array}{c}0.002 * * * \\
(12.44)\end{array}$ & $\begin{array}{c}0.002 * * * \\
(15.11)\end{array}$ & $\begin{array}{c}0.0006^{* * * *} \\
(6.24)\end{array}$ & $\begin{array}{c}0.0006^{* * * *} \\
(5.73)\end{array}$ & $\begin{array}{c}0.002 * * * \\
(11.62)\end{array}$ & $\begin{array}{c}0.002 * * * \\
(18.90)\end{array}$ \\
\hline LOAN & + & $\begin{array}{c}0.0001 * * * \\
(3.57)\end{array}$ & $\begin{array}{c}0.0001 * * * * \\
(3.04)\end{array}$ & $\begin{array}{c}0.0001 * * * * \\
(3.57)\end{array}$ & $\begin{array}{c}0.0001 * * * \\
(3.06)\end{array}$ & $\begin{array}{c}-0.0001 * * \\
(-2.42)\end{array}$ & $\begin{array}{c}-0.0001 * * \\
(-2.21)\end{array}$ & $\begin{array}{c}0.0001 * * * \\
(3.61)\end{array}$ & $\begin{array}{c}0.0001 * * * \\
(3.09)\end{array}$ \\
\hline CAR & - & $\begin{array}{c}-0.0001 \\
(-0.11)\end{array}$ & $\begin{array}{c}0.0002 \\
(0.30)\end{array}$ & $\begin{array}{l}-0.0001 \\
(-0.12)\end{array}$ & $\begin{array}{c}0.00002 \\
(0.37)\end{array}$ & $\begin{array}{c}-0.0002^{*} \\
(-1.94)\end{array}$ & $\begin{array}{c}-0.0002^{*} \\
(-1.66)\end{array}$ & $\begin{array}{c}0.0002 \\
(0.25)\end{array}$ & $\begin{array}{c}0.0004 \\
(0.51)\end{array}$ \\
\hline SIZE & + & $\begin{array}{c}-0.0001 \\
(-0.49) \\
\end{array}$ & $\begin{array}{c}-0.0001 \\
(-0.46) \\
\end{array}$ & $\begin{array}{c}-0.0001 \\
(-0.27) \\
\end{array}$ & $\begin{array}{c}-0.0001 \\
(-0.26) \\
\end{array}$ & $\begin{array}{c}0.0004^{* *} \\
(1.98) \\
\end{array}$ & $\begin{array}{c}0.0006 * * * \\
(2.92)\end{array}$ & $\begin{array}{c}-0.0001 \\
(-0.17) \\
\end{array}$ & $\begin{array}{c}-0.00003 \\
(-0.08) \\
\end{array}$ \\
\hline$\Delta \mathrm{GDP}$ & - & $\begin{array}{c}-0.0004 * * * \\
(-3.37)\end{array}$ & $\begin{array}{c}-0.005 * * * \\
(-3.65)\end{array}$ & $\begin{array}{c}-0.0004 * * * \\
(-3.30)\end{array}$ & $\begin{array}{c}-0.0005 * * * \\
(-3.59)\end{array}$ & $\begin{array}{c}-0.0004 * * * \\
(-3.46)\end{array}$ & $\begin{array}{c}-0.0003 * * \\
(-2.27)\end{array}$ & $\begin{array}{c}-0.0004 * * * \\
(-2.69)\end{array}$ & $\begin{array}{c}-0.0005^{* * * *} \\
(-2.91)\end{array}$ \\
\hline LISTED*EBTP & + & & & $\begin{array}{l}0.114 \\
(0.92) \\
\end{array}$ & & & & & \\
\hline LISTED & $?$ & & & $\begin{array}{l}-0.001 \\
(-0.72) \\
\end{array}$ & $\begin{array}{l}-0.001 \\
(-0.62) \\
\end{array}$ & & & & \\
\hline LISTED*POST*EBTP & $?$ & & & & $\begin{array}{l}0.116 \\
(1.04)\end{array}$ & & & & \\
\hline Adjusted $\mathrm{R}^{2}$ & & 60.86 & 60.85 & 60.78 & 60.86 & 62.44 & 66.27 & 61.60 & 61.57 \\
\hline $\begin{array}{c}\text { F-stat } \\
\text { (p-value) }\end{array}$ & & $\begin{array}{l}141.20 \\
(0.000) \\
\end{array}$ & $\begin{array}{l}106.14 \\
(0.000) \\
\end{array}$ & $\begin{array}{l}105.78 \\
(0.000) \\
\end{array}$ & $\begin{array}{c}94.47 \\
(0.000) \\
\end{array}$ & $\begin{array}{c}30.64 \\
(0.000) \\
\end{array}$ & $\begin{array}{c}27.28 \\
(0.000) \\
\end{array}$ & $\begin{array}{l}116.78 \\
(0.000) \\
\end{array}$ & $\begin{array}{c}87.35 \\
(0.000) \\
\end{array}$ \\
\hline Observation & & 542 & 542 & 542 & 542 & 108 & 108 & 434 & 434 \\
\hline $\begin{array}{l}* * *, * * \text { and } * \text { denotes si } \\
\text { is the natural logarithm } \\
\text { of impaired loans to gro } \\
\text { variable that take the val } \\
\text { term that measures the } \mathrm{e} \\
\text { interaction term that me }\end{array}$ & $\begin{array}{l}\text { icar } \\
\text { tal } \\
\text { ans } \\
\text { one } \\
\text { t th }\end{array}$ & $\begin{array}{l}\text { evels at the } \\
\text { ts. LOAN is } \\
\text { iDP is chan } \\
\text { ost-crisis p } \\
\text { anks use pro } \\
\text { xtent that lis }\end{array}$ & $\begin{array}{l}1,0.05 \text { and } 0 \\
\text { change in } \mathrm{g} \\
\mathrm{n} \text { gross dom } \\
\text { d from } 2009 \\
\text { ions to smoo }\end{array}$ & $\begin{array}{l}\text {, respective } \\
\text { s loans out } \\
\text { ic product. } \\
2013 \text {, and } \\
\text { income in tl }\end{array}$ & $\begin{array}{l}\text { EBTP is the } \\
\text { ding. LLP is } \\
\text { is tier } 1 \text { reg } \\
\text { for the pre- } \\
\text { ost-crisis pe }\end{array}$ & $\begin{array}{l}\text { o of pre-tax } \\
\text { ratio of loa } \\
\text { tory capital } \\
\text { s period fro } \\
\text { relative to }\end{array}$ & $\begin{array}{l}\text { ore-provisic } \\
\text { provisions } \\
\text { k-weighted } \\
04 \text { to } 2007 . \\
\text { e-crisis per } \\
\text { banks. }\end{array}$ & $\begin{array}{l}\text { rnings to } t \\
\text { tal assets. } \\
\text { ratio. POS } \\
T^{*} \text { EBTP is } \\
\text { ISTED*E }\end{array}$ & $\begin{array}{l}\text { Ssets. SIZE } \\
\text { is the ratio } \\
\text { a dummy } \\
\text { interaction } \\
\text { is the }\end{array}$ \\
\hline
\end{tabular}




\begin{tabular}{|c|c|c|c|c|c|}
\hline \multicolumn{6}{|c|}{ Table 4: Regression (Sensitivity Analysis) } \\
\hline & & \multicolumn{2}{|c|}{ Full Sample (Pre-crisis) } & \multicolumn{2}{|c|}{ Full Sample (Post-crisis) } \\
\hline & & (1) & (2) & (3) & (4) \\
\hline Variable & $\begin{array}{l}\text { Expected } \\
\text { Sign }\end{array}$ & $\begin{array}{c}\text { coefficient } \\
\text { t-statistic }\end{array}$ & $\begin{array}{c}\text { coefficient } \\
\text { t-statistic }\end{array}$ & $\begin{array}{c}\text { coefficient } \\
\text { t-statistic }\end{array}$ & $\begin{array}{c}\text { coefficient } \\
\text { t-statistic }\end{array}$ \\
\hline $\mathrm{c}$ & $?$ & $\begin{array}{c}-0.005 * * \\
(-1.99)\end{array}$ & $\begin{array}{c}-0.007 * * \\
(-2.37)\end{array}$ & $\begin{array}{c}-0.007 * \\
(-1.71)\end{array}$ & $\begin{array}{l}-0.003 \\
(-0.43)\end{array}$ \\
\hline EBTP & + & $\begin{array}{c}0.149 * * * \\
(4.76)\end{array}$ & $\begin{array}{c}0.177 * * * \\
(4.77)\end{array}$ & $\begin{array}{c}0.341 * * * \\
(7.17)\end{array}$ & $\begin{array}{l}0.037 \\
(0.55)\end{array}$ \\
\hline LISTED*EBTP & $+/-$ & & $\begin{array}{l}-0.075 \\
(-1.03) \\
\end{array}$ & & $\begin{array}{l}0.223 \\
(1.29) \\
\end{array}$ \\
\hline LISTED & $?$ & & $\begin{array}{c}0.0002 \\
(0.27)\end{array}$ & & $\begin{array}{l}-0.002 \\
(-0.96)\end{array}$ \\
\hline NPL & + & $\begin{array}{c}0.0007 * * * \\
(7.53)\end{array}$ & $\begin{array}{c}0.001 * * * \\
(4.77) \\
\end{array}$ & $\begin{array}{c}0.0006^{* * * *} \\
(6.24)\end{array}$ & $\begin{array}{c}0.002 * * * \\
(12.51)\end{array}$ \\
\hline LOAN & + & $\begin{array}{c}-0.0002 * \\
(-1.85) \\
\end{array}$ & $\begin{array}{c}-0.0001 * * \\
(-1.96) \\
\end{array}$ & $\begin{array}{c}-0.0001 * * \\
(-2.42) \\
\end{array}$ & $\begin{array}{c}-0.0001 * * \\
(-2.21) \\
\end{array}$ \\
\hline CAR & - & $\begin{array}{l}0.0001 \\
(1.29)\end{array}$ & $\begin{array}{c}0.0001 \\
(1.31)\end{array}$ & $\begin{array}{c}-0.0002^{*} \\
(-1.94)\end{array}$ & $\begin{array}{c}-0.0001 \\
(-0.63)\end{array}$ \\
\hline SIZE & + & $\begin{array}{c}0.0002^{*} \\
(1.72)\end{array}$ & $\begin{array}{c}0.0003 * * \\
(2.07) \\
\end{array}$ & $\begin{array}{c}0.0004^{* *} \\
(1.98) \\
\end{array}$ & $\begin{array}{c}-0.00003 \\
(-0.09) \\
\end{array}$ \\
\hline$\Delta \mathrm{GDP}$ & - & $\begin{array}{c}-0.0006 \\
(-0.35) \\
\end{array}$ & $\begin{array}{c}-0.0001 \\
(-0.48) \\
\end{array}$ & $\begin{array}{c}-0.0004 * * * \\
(-3.46)\end{array}$ & $\begin{array}{c}-0.0005 * * * \\
(-3.46)\end{array}$ \\
\hline Adjusted $\mathrm{R}^{2}$ & & 34.01 & 34.23 & 62.44 & 61.04 \\
\hline $\begin{array}{c}\text { F-stat } \\
\text { (p-value) }\end{array}$ & & $\begin{array}{c}14.57 \\
(0.000) \\
\end{array}$ & $\begin{array}{c}11.28 \\
(0.000) \\
\end{array}$ & $\begin{array}{c}30.64 \\
(0.000) \\
\end{array}$ & $\begin{array}{c}75.79 \\
(0.000) \\
\end{array}$ \\
\hline Observation & & 159 & 159 & 108 & 383 \\
\hline \multicolumn{6}{|c|}{$\begin{array}{l}* * *, * * \text { and } * \text { denotes significance levels at the } 0.01,0.05 \text { and } 0.10 \text {, respectively. EBTP is the ratio of pre-tax and pre- } \\
\text { provisions earnings to total assets. SIZE is the natural logarithm of total assets. LOAN is the change in gross loans } \\
\text { outstanding. LLP is the ratio of loan loss provisions to total assets. NPL is the ratio of impaired loans to gross loans. } \Delta \text { GDP } \\
\text { is change in gross domestic product. CAR is tier } 1 \text { regulatory capital. LISTED is a dummy variable that take the value one } \\
\text { for listed Western European banks, and zero otherwise. LISTED*EBTP is the interaction term that measures the extent that } \\
\text { listed banks use provisions to smooth income compared to non-listed banks. }\end{array}$} \\
\hline
\end{tabular}

